Gut, 1984, 25, 460-464

\title{
Rates of whole body protein synthesis and breakdown increase with the severity of inflammatory bowel disease
}

\author{
J POWELl-TUCK, P J GARLICK, J E LENNARD-JONES, AND J C WATERLOW \\ From the Department of Human Nutrition, London School of Hygiene and Tropical Medicine, London, and \\ St Marks's Hospital, City Road, London
}

SUMmARY Rates of whole body protein synthesis and breakdown were estimated in 19 undernourished patients with inflammatory bowel disease from the cumulative nine hour excretion of urinary ${ }^{15} \mathrm{NH}_{3}$ after intravenous injection of ${ }^{15} \mathrm{~N}$ glycine. Thirty six studies were made during constant nutrient input either parenterally by 3 litre bag technique ( 29 studies), or enterally by nasogastric infusion of protein containing liquid feeds (four studies), or by diet kitchen prepared food eaten at two hourly intervals (three studies). Mean daily intakes were $50 \cdot 7$ $\mathrm{kcal}$ and $0.29 \mathrm{~g}$ nitrogen $/ \mathrm{kg}$ body weight. Synthesis and break down rates correlated significantly with disease activity as judged by erythrocyte sedimentation rate and by ranking by an observer unaware of the turnover results. Rates for synthesis and breakdown by this method were about $2 \cdot 1$ and $1.7 \mathrm{~g}$ protein $/ \mathrm{kg} / 24 \mathrm{~h}$ respectively for ESR 10 increasing to 4.0 and $3 \cdot 3$ for ESR 100 .

Inflammation and sepsis ${ }^{1}$ like trauma ${ }^{2}$ result in increased losses of nitrogen from the body and can result in negative nitrogen balance and protein undernutrition. Most infective illnesses are short lived with appropriate treatment, and the modest losses of lean body mass are rapidly restored during convalescence; however, in more chronic disease, nutritional support sometimes becomes necessary.

In active inflammatory bowel disease, substantial losses of lean body mass can occur. ${ }^{3}$ Nitrogen intake is reduced because of diminished appetite; protein is lost into the intestinal lumen and it and its digested by-products are lost as faecal nitrogen. ${ }^{4}$ These losses are associated with proportionate increases in fractional losses of proteins like albumin and immunoglobulin $\mathrm{G}$ from the blood. ${ }^{5}$ In addition to decreased intake and increased losses it seems likely that there is also an effect of the inflammatory process per se on protein metabolism akin to that occurring in infectious disease, about which little is known.

Nitrogen losses from the body caused by changes in protein metabolism occur if average breakdown rates exceed average protein synthetic rates. That is not to say that breakdown rates must be higher than normal, for net loss of nitrogen occurs if synthesis

Address for correspondence: Dr J Powell-Tuck. Dept of Gastroenterology. Charing Cross Hospital. Fulham Palace Road. London W6 8RF.

Received for publication 29 July 1983 falls with normal breakdown rates. Similarly, net nitrogen loss can occur when there are higher than normal synthetic rates, if breakdown rates are still further raised.

We have measured whole body protein synthesis and breakdown rates in undernourished patients with inflammatory bowel disease while they were receiving nutritional treatment. The method used was designed for use in a clinical setting and is suitable even for severely ill patients. It requires no special equipment by the bedside, does not require faecal collections to be made, and because it uses a stable isotope, ${ }^{15} \mathrm{~N}$, can be repeated even in young patients. Because the response of protein metabolism to the inflammation is determined independently of stool nitrogen losses, the study aimed to give information on how protein metabolism responds to inflammation in general, as well as to provide more specific guidance about the nutritional treatment of inflammatory bowel disease.

\section{Methods}

PATIENTS

Whole body protein turnover (synthesis and breakdown) was measured after intravenous introduction of a tracer dose of ${ }^{15} \mathrm{~N}$ glycine by the method of Waterlow et al, ${ }^{6}$ with urinary ammonia as the end product. Nineteen patients (eight women, 11 men) 
with ulcerative colitis or Crohn's disease, who were receiving enteral or parenteral feeding for clinical reasons, were studied on 36 occasions. Their mean age was 35 years (range 16-76 years) and the distribution of the disease was colonic in seven patients (three ulcerative colitis), ileocolic in two. extensive throughout the small bowel in two and in eight there had been a post-resectional ileal recurrence.

Those patients studied were undernourished as judged by the Quetelet index, with men having a mean index of $19 \cdot 8$ (range $16 \cdot()-27 \cdot 1)$ and women a mean index of 16.9 (range 15.7-18.2). The Quetelet index (weight in kilograms divided by height in metres squared) has been shown to be a good index of nutrition ${ }^{7}$ with mean values in a normal London population of 25 (range 24-27) in men and 26 (range 23-29) in women. ${ }^{\times}$The nitrogen intake averaged $0.29 \mathrm{~g} / \mathrm{kg} / 24 \mathrm{~h}$ (range $0-() \cdot 4)$ and the energy intake averaged $50 \cdot 7 \mathrm{kcal} / \mathrm{kg} / 24 \mathrm{~h}$ (range $6 \cdot(-92 \cdot 1$ ). The low ends of the ranges refer to one patient on one occasion studied while receiving 5\% dextrose after a run in period of 24 hours. Fifteen patients (29 studies) received their nutrients parenterally from 3 litre bags containing a full 24 hour feed infused at constant rate by pump. ${ }^{9}$ During the period of this study the feed supplied energy as glucose and amino acids. The amino acid source was electrolyte containing Synthamin (Travenol Laboratories Ltd). The feed was supplemented with calcium, magnesium, vitamins (except vitamin $\mathrm{D}$ and biotin), and trace elements $(\mathrm{Zn}, \mathrm{Cu}, \mathrm{Se}, \mathrm{I}, \mathrm{Cr})$. Phosphate $(30 \mathrm{mmol} / \mathrm{l})$ is present in the Synthamin. Iron supplements were given enterally or parenterally in iron deficient patients. Three patients (four studies) received nutritionally complete nasogastric feeds containing protein and fat which were infused at constant rate by pump. One patient was studied after an overnight fast on three occasions while receiving a weighed diet prepared in the diet kitchen and consumed in equal portions at two hourly intervals, two hours before and during the study. This one patient was thus studied in accordance with the standard protocol for this method in use at the clinical nutrition and metabolism unit. The remainder were studied after longer run in periods of constant nutrient intake. They were on essentially constant feeds for $13 \pm 2.5$ (SEM) days before each study except that the parenterally fed patients received supplements of a minimum of 1 litre intralipid $20 \%$ per week before but not during the studies. An identical constant nutrient intake to that used during the tests was maintained for 48 hours before each study. Fourteen of the patients required surgery during their stay in hospital but all studies included in this paper were done preoperatively.
During the study the patients received a constant nutrient input as above, with no additional intake except plain water as desired. The bladder was initially emptied and the urine collected and subsequently analysed for baseline ${ }^{15} \mathrm{~N}$ abundance $\left({ }^{15} \mathrm{~N} /\right.$ ${ }^{14} \mathrm{~N}$ as a percentage) in ammonia. A slow intravenous injection of $100-200 \mathrm{mg}{ }^{15} \mathrm{~N}$ glycine was given over the first hour and three accurately timed consecutive three hour urine collections were made to obtain ${ }^{15} \mathrm{~N}$ abundances in ammonia over the nine hours after the beginning of tracer administration. There then followed a further urine collection over the next 15 hours so that 24 hour nitrogen and 3 methyl histidine excretion could be measured.

The flux of amino $\mathrm{N}$ through a theoretical whole body precursor pool for protein synthesis is given by the dose of tracer $\mathrm{N}$ divided by the abundance of ${ }^{15} \mathrm{~N}$ in ${ }^{14} \mathrm{~N}$ in the ammonia formed and excreted over the nine hours after the administration of a tracer. ${ }^{6}$ Synthesis and breakdown are calculated by subtracting urinary $\mathrm{N}$ excretion and the known $\mathrm{N}$ input from the flux. ${ }^{15} \mathrm{~N}$ abundances were measured on a single collector mass spectrometer (AEI, Manchester, UK). Nitrogen output was obtained by the micro-Kjeldahl method. Urinary 3 methyl histidine was measured on a Locarte amino acid analyser. Urine ammonia was measured by titration after trapping in boric acid.

The severity of the patient's inflammatory bowel disease was estimated by two methods. Firstly erythrocyte sedimentation rate (Westergren) was determined, and secondly the patients were ranked in order of severity by an experienced observer (JEL-J) who was unaware of the protein turnover results. He knew all the patients and had access to other clinical and laboratory data.

\section{Results}

All but one patient had ESR results. The rates of protein synthesis and breakdown expressed as grams protein per $\mathrm{kg}$ per 24 hours correlated significantly with ESR (Fig. 1), rising from levels of about 2.1 and 1.7 respectively at a normal ESR of 10 to about double (4.0 and 3.3 respectively) at an ESR of 100 . Synthesis $(\tau=0.52 ; n=19 ; \quad p<0.0027)$ correlated significantly with severity rank as judged by Kendall's method of rank correlation. Rank correlated with ESR $(r=0.48 ; p<0.01)$.

There was no correlation between disease severity (rank) and either the absolute urinary ammonia excretion $(\tau=0.04)$ or the urinary ammonia:urinary nitrogen ratio $(r=0.09)$. There was no significant correlation between protein synthesis and Quetelet index $(r=0 \cdot 28)$, nitrogen intake $(r=0 \cdot 24)$, energy intake $(r=0.06)$, or plasma albumin concentration 


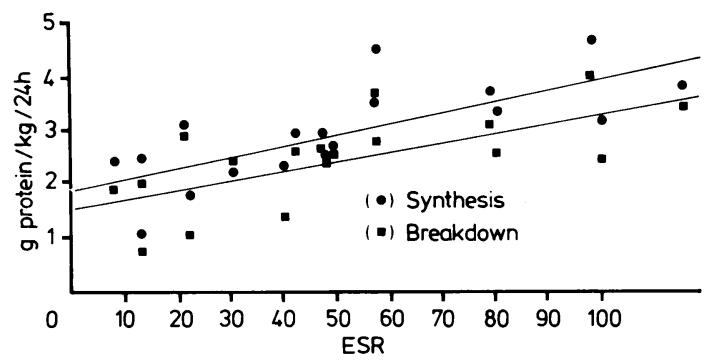

Fig. 1 Mean rates of whole body protein sythesis and breakdown compared with ESR in $18^{*}$ patients with inflammatory bowel disease. Synthesis: $r=0 \cdot 73, p<0 \cdot 001$; breakdown: $r=0 \cdot 69, p<0 \cdot 01$

* One patients did not have ESR determination.

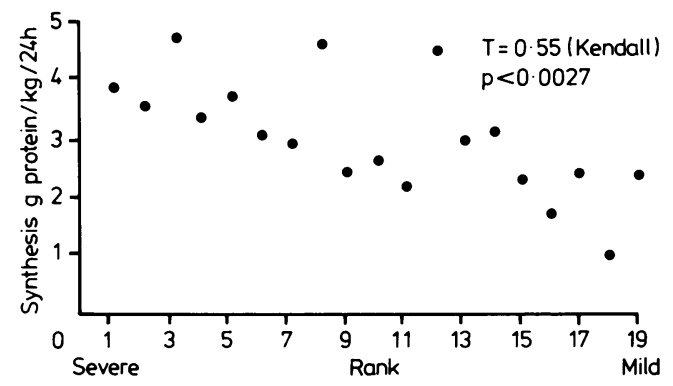

Fig. 2 Mean rates of whole body synthesis ranked according to disease severity. $T=0.55$ (Kendall), $p<0.0027$.

the intensity of the inflammation, whether or not there is associated abscess formation and whether there is any intestinal obstruction. The erythrocyte sedimentation rate is a measurement widely accepted as an index of inflammatory response, which correlates with other measures of inflammatory bowel disease such as $C$ reactive protein $;{ }^{11}$ it therefore seemed appropriate to use it in this study, particularly with its advantages of simplicity and widespread availability. Overall clinical ranking, also used as a method of assessment, can take account of the varied clinical features in each case, whether the patients have ulcerative colitis or Crohn's disease. The present results by this ammonia end product method show that with disease regarded as mild in severity or associated with normal ESR, synthesis proceeds at about $2 \mathrm{~g}$ protein $/ \mathrm{kg}$ protein $/ \mathrm{kg}$ body weight $/ 24 \mathrm{~h}$, with breakdown rates a little less. Such rates are very similar to those found in fed normal individuals by Fern et al with the same technique. ${ }^{13}$ More severely ill patients (ESR 100), however, had rates approximately double and there was a significant correlation between protein synthesis and breakdown and disease severity. Such a correlation could be regarded as an artefact if more severe disease resulted in increased urinary ammonia excretion or changes in the urinary ammonia:nitrogen ratio but no such changes were observed. Moreover we have evidence (to be published) that the amount of ammonia excreted has little or no effect on the flux. In a study like this, in which, a relatively large number of patients with very variable disease distributions and severity are included, we must make sure that other factors are not causing us to make false conclusions. No significant difference, however, in turnover rates between obstructed and unobstructed patients, those on and off steroids (or
Assessment of the severity of inflammatory bowel disease, particularly Crohn's disease, is difficult. The severity depends upon the extent of the disease, 
other drugs), those pyrexial or not, or those receiving enteral or parenteral nutrition were observed. This is not to say that these factors in reality have no effect on protein turnover, merely to suggest that they were not dominant confounding factors here.

It could be argued that patients who had lost more weight tended to receive the larger inputs of nitrogen or energy per kilogram, thus resulting in a false correlation. No correlation existed, however, between ESR and Quetelet index (weight/height ${ }^{2}$ ) $(r=-0 \cdot 16)$ or between ESR and nitrogen intake per kilogram body weight $(r=0.09)$. Nor was there any correlation between energy intake and protein turnover. It seems therefore that any tendency (though statistically insignificant) for protein synthesis to vary with Quetelet index or inversely with plasma albumin concentration was because these parameters tended to vary with disease severity. The lack of correlation between intake of nitrogen and energy with protein turnover suggests to us that the majority of studies were conducted under conditions of optimal or supraoptimal energy and nitrogen intake.

It is not suggested that all the different body proteins which together constitute whole body protein responded to the stress of illness, even qualitatively, in the same way - it is very likely that they do not. Nevertheless, it is of interest to estimate the response of the body's protein on average. The results here suggest that, overall, both protein synthesis and protein breakdown rates increase with disease severity in the fed state.

This finding is consistent with that of Garlick et al $^{14}$ who showed increases in turnover in response to typhoid-cholera inoculation and with that of Long et $a l^{15}$ who found increased protein turnover in septic patients. Similarly Tomkins et al ${ }^{16}$ working in Nigeria, have found increases in rates of protein turnover in infected children, which tends to be counteracted by malnutrition. In these studies protein turnover has been measured with $15-\mathrm{N}$ glycine or alanine, with urea or ammonia as end products. It is of interest that Clague,${ }^{17}$ using 14-C leucine, has reported an increase in protein turnover rate in surgical patients, positively correlated with the degree of injury. These results obtained by a totally different approach therefore tend to validate our conclusions based on the $15-\mathrm{N}$ end-product method.

We are grateful to the sisters and nursing staff of St Mark's Hospital, particularly Miss Susanne Wood, for their help during this study. Dr Edward Fern gave helpful advice. We thank also Miss Hilda Shepherd and Mr Philip Broadbent of the Clinical
Nutrition and Metabolism Unit for their skilled technical assistance. The Department of Medical Illustration, Charing Cross Hospital, prepared the figures and Mrs Christine Smith typed the manuscript. JP-T was supported by a Wellcome research fellowship.

\section{References}

1 Beisel WR. Interrelated changes in host metabolism during generalised infectious illness. Am J Clin Nutr 1972; 25: 1254-60.

2 Cuthbertson DP, Tilstone WJ. Metabolism during the post injury period. Adv Clin Chem 1969; 12: 1-55.

3 Dickinson RJ, Ashton MG, Axon ATR, Smith RC, Yeung CK, Hill GL. Controlled trial of intravenous hyperalimentation and total bowel rest as an adjunct to the routine treatment of acute colitis. Gastroenterology 1980; 79: 1199-204.

4 Welch CS, Adams M, Wakefield EG. Metabolic studies in ulcerative colitis. J Clin Invest 1937; 16: 161-8.

5 Jarnum S, Jensen KB. Faecal radio-iodide excretion following intravenous injection of ${ }^{1.31} 1$ albumin and ${ }^{125} 1$ immunoglobulin $G$ in chronic inflammatory bowel disease: an aid to topographic diagnosis. Gastroenterology 1975; 68: 1433-44.

6 Waterlow JC, Golden MHN, Garlick PJ. Protein turnover in man measured with ${ }^{15} \mathrm{~N}$ : comparison of end-products and dose regimes. Am J Physiol 1978 : 235: E165-E74.

7 Khosla $T$, Lowe CR. Indices of obesity derived from body weight and height. BrJ Prev Soc Med 1967; 21: 122-8.

8 Baird IM, Silverstone JT, Grimshaw JJ, Ashwell M. Prevalence of obesity in a London Borough. Practitioner 1974; 212: 706-14.

9 Powell-Tuck J, Nielsen T, Farwell JA, Lennard-Jones JE. Team approach to long term intravenous feeding in patients with gastrointestinal disorders. Lancet 1978; 2: 825-8.

10 Young VR, Munro HN. N methyl histidine (3 methyl histidine) and muscle protein turnover - an overview. Fed Proc 1978; 37: 2291-300.

11 Andre C, Descos L, Landais P, Fermanian J. Assessment of appropriated laboratory measurements to supplement the Crohn's disease activity index. Gut 1981; 22: 571-4.

12 Best WR, Becktel JM, Singleton JW, Kern F. Development of a Crohn's disease activity index - National Cooperative Crohn's disease study. Gastroenterology 1976; 70: 439-44.

13 Fern EB, Garlick PJ, McNurlan MA, Waterlow JC. The excretion of isotope in urea and ammonia for estimating protein turnover in man with $\left({ }^{15} \mathrm{~N}\right)$ glycine. Clin Sci 1981; 61: 217-28.

14 Garlick PJ, McNurlan MA. Fern EB, Tomkins AM, Waterlow JC. Stimulation of protein synthesis and breakdown by vaccination. $\mathrm{Br}$ Med J 1980; 281: 263-4. 
15 Long CL, Jeevandam M, Kim BM, Kinney JM. Whole body protein synthesis and catabolism in septic man. Am J Clin Nutr 1977; 30: 1340-4.

16 Tomkins AM, Garlick PJ, Schofield WN, Waterlow JC. The combined effects of infection and malnutrition on protein metabolism in children. Clin Sci 1983; 65: 313-24.

17 Clague MB, Keir MJ, Wright PD, Johnston IDA. The effects of nutrition and trauma on whole-body protein metabolism in man. Clin Sci 1983; 65: 165-75. 